L. V. Savchenkova ${ }^{1}$, M. N. Saidova ${ }^{1}$, N. S. Sanginova ${ }^{1}$, I. P. Jabarov ${ }^{2}$

${ }^{1}$ Tajik National University

${ }^{2}$ Y. B. Iskhaki Khujand State Medical College

\title{
Pharmacoepidemiological analysis of the use of antibacterial drugs in the pulmonary department of the multi-specialty hospital of the Republic of Tajikistan
}

The uncontrolled and excessive use of antibiotics in infectious diseases significantly reduces the effectiveness of the drug therapy, increases the risk of adverse reactions, increases the cost of treatment and, most importantly, promotes the growth and spread of antibiotic resistance. Monitoring of the consumption of this group of drugs for systemic use is one of the most important methods used in the system of measures to improve prescribing practices of this group.

Aim. To analyze the consumption of antimicrobial agents in the pulmonary department of the multi-specialty hospital using the DDD-methodology.

Materials and methods. The retrospective descriptive analysis of prescribing pharmacotherapy for patients being treated in the pulmonary department of the Sughd regional clinical hospital (Khujand, Tajikistan) was performed. Using the ATC/DDD-methodology the consumption of antimicrobial agents was studied. As a unit of measurement the grams of the active substance was used with the subsequent calculation of the indicator of DDD/100 bed-days and the percentage of the total DDD.

Results and discussion. The DDD-analysis of the consumption of antimicrobial drugs on the example of the pulmonary department of the multi-specialty hospital showed a significant change in the structure of the drug consumption in this group for the starting antibiotic therapy of respiratory tract infections over the past five years. A clear downward tendency was identified in the consumption of drugs of penicillin and macrolides with the transition to monotherapy with cephalosporins of the 3-rd generation (ceftriaxone) and partially fluoroquinolones.

Conclusions. Monitoring of the consumption of antimicrobials in in-patient departments using the ATC/DDDmethodology allows to make strategic decisions concerning the tactics of antibiotic treatment of diseases according to the department specialization, as well as to determine the direction of administrative measures for further improvement of the range of antibacterial drugs introducing modern effective products into practice and optimizing the consumption of antibiotics in each specific department.

Key words: pharmacoepidemiology; antibiotics; community-acquired pneumonia

Л. В. Савченкова, М. Н. Саїдова, Н. С. Сангінова, І. П. Джабаров

Фармакоепідеміологічний аналіз використання антибактеріальних препаратів у пульмонологічному відділенні багатопрофрільного стаціонару Республіки Таджикистан

Неконтрольоване і надмірне застосування антибіотиків при інфекційних захворюваннях істотно знижує ефективність проведеної фрармакотерапії, підвищує ризик розвитку небажаних реакцій, здорожує лікування i, що особливо важливо, сприяє зростанню і поширенню антибіотикорезистентності. Саме моніторинг споживання даної групи препаратів для системного застосування є одним з найважливіших методів, що використовуються в системі заходів щодо поліпшення практики призначення лікарських засобів даної групи.

Метою $є$ аналіз споживання антимікробних препаратів у пульмонологічному відділенні багатопрофільного стаціонару з використанням DDD-методології.

Матеріали та методи. Здійснено ретроспективний описовий аналіз лікарських призначень при фрармакотерапії пацієнтів, які перебувають на лікуванні в пульмонологічному відділенні Согдігської обласної клінічної лікарні (м. Худжанд, Республіка Таджикистан). За допомогою ATC/DDD-методології вивчено споживання антимікробних препаратів. В якості одиниці вимірювання використовувалася кількість грамів активної речовини 3 подальшим розрахунком показника DDD/100 ліжко-днів і \% від загальної DDD.

Результати та їх обговорення. Проведення DDD-аналізу споживання антимікробних препаратів на прикладі пульмонологічного відділення багатопрофільного стаціонару показало істотну зміну структури споживання даної групи лікарських засобів для стартової антибактеріальної терапії інфекцій дихальних шляхів за останні п'ять років. Виявлено явну тенденцію до зниження споживання препаратів пеніцилінового ряду і макролідів 3 переходом на монотерапію цефралоспоринами 3 покоління (цефтриаксон) і частково фрторхінолонами.

Висновки. Моніторинг споживання антимікробних препаратів у відділеннях стаціонару з використанням ATC/DDD-методології дозволяє приймати стратегічні рішення щодо тактики антибіотикотерапії захворювань згідно з профілем відділення, визначити напрямок адміністративних заходів, що дозволить у подальшому покращити асортимент антибактеріальних препаратів з введенням у практику сучасних ефективних препаратів i оптимізувати споживання антибіотиків у кожному конкретному відділенні.

Ключові слова: фрармакоепідеміологія; антибіотики; позалікарняна пневмонія 


\section{Л. В. Савченкова, М. Н. Саидова, Н. С. Сангинова, И. П. Джабаров \\ Фармакоэпидемиологический анализ использования антибактериальных препаратов в пульмонологическом отделении многопрофильного стационара Республики Таджикистан}

Неконтролируемое и чрезмерное применение антибиотиков при инфекционных заболеваниях существенно снижает эффективность проводимой фрармакотерапии, повышает риск развития нежелательных реакций, удорожает лечение и, что особенно важно, способствует росту и распространению антибиотикорезистентности. Именно мониторинг потребления данной группы препаратов для системного применения является одним из важнейших методов, используемых в системе мер по улучшению практики назначения лекарственных средств данной группы.

Целью является анализ потребления антимикробных препаратов в пульмонологическом отделении многопрофильного стационара с использованием DDD-методологии.

Материалы и методы. Осуществлен ретроспективный описательный анализ врачебных назначений при фармакотерапии пациентов, находящихся на лечении в пульмонологическом отделении Согдигской областной клинической больницы (г. Худжанд, Республика Таджикистан). С помощью ATC/DDD-методологии изучено потребление антимикробных препаратов. В качестве единицы измерения использовалось количество граммов активного вещества с дальнейшим расчетом показателя DDD/100 койко-дней и \% от общей DDD.

Результаты и их обсуждение. Проведение DDD-анализа потребления антимикробных препаратов на примере пульмонологического отделения многопрофильного стационара показало существенное изменение структуры потребления данной группы лекарственных средств для стартовой антибактериальной терапии инфекций дыхательных путей за последние пять лет. Выявлена явная тенденция к снижению потребления препаратов пенициллинового ряда и макролидов с переходом на монотерапию цефалоспоринами 3 поколения (цефртриаксон) и частично фрторхинолонами.

Выводы. Мониторинг потребления антимикробных препаратов в отделениях стационара с использованием ATC/DDD-методологии позволяет принимать стратегические решения в отношении тактики антибиотикотерапии заболеваний, согласно профиля отделения, определить направление административных мер, позволивших в дальнейшем улучшить ассортимент антибактериальных препаратов с введением в практику современных эффективных препаратов и оптимизировать потребление антибиотиков в каждом конкретном отделении.

Ключевые слова: фрармакоэпидемиология; антибиотики; внебольничная пневмония

Monitoring of the consumption of antimicrobial drugs (ADs) for systemic use is one of the most important methods used in the system of measures to improve prescribing practices of this group. It is known that ADs are often unreasonably prescribed in clinical practice [1-3]. The uncontrolled and excessive use of ADs in infectious diseases significantly reduces the effectiveness of the drug therapy, increases the risk of adverse reactions, increases the cost of treatment and, most importantly, promotes the growth and spread of antibiotic resistance [2]. Unfortunately, medical professionals do not consider the group of antibacterial drugs as medicines, which use can lead to serious medical and economic consequences.

Currently, monitoring of the drug consumption has become an integral part of assessment of using ADs in hospitals in many countries. For more than 15 years the results of monitoring of the system $\mathrm{AD}$ consumption are collected in more than 30 countries in Europe [1, 4]. Thus, according to the Ministry of Health in Russia 20-75\% of cases of AD use are irrational $[3,5]$. Analysis of the consumption of ADs in in-patient departments identifies problems related to their excessive or insufficient use.

Based on the results of such studies there is the opportunity to optimize the use of medicines, including ADs, in hospitals, redistribute financial flows in the groups of drugs with improvement of the drug range used and the treatment quality, and it is an important task in the conditions of the limited financing of healthcare institutions (HCIs) according to the article "Medicines". At the same time in the Republic of Tajikistan such studies are inconsiderable in number, and information on $\mathrm{AD}$ consumption at the level of the republic, regions and individual hospitals is fragmentary and uncoordinated. One of the methods of analysis is pharmacoepidemiological ATC/DDD-methodology, which provides quantitative data on $\mathrm{AD}$ consumption and allows to compare them in different departments, HCIs, regions, countries. Since 1996 it is ATC/DDD-methodology that is an international standard for research on the drug consumption $[2,6]$. DDD is a defined daily dose of a medicine for an adult with the weight of $70 \mathrm{~kg}$ developed by the WHO Center according to the Drug Statistics Methodo$\operatorname{logy}[2,7]$. The DDD-analysis is a method of examination of the rationality of drug prescribing, which gives an overall picture of the drug use and allows to make appropriate management decisions $[6,8]$.

The DDD-monitoring of antibiotics allows to obtain the real data on their use and assess tendencies of using this group of drugs in a particular hospital, or department in the course of time $[2,7,9]$. As already mentioned, the importance of the rational use of ADs in the treatment of various diseases of the infectious origin is caused not only by the danger of disease progression, but also by the possibility of developing antibiotics resistance to specific drugs, and the AD group as a whole.

The aim of the study was to analyze the consumption of antimicrobial agents in the pulmonary department of the multi-specialty hospital using the DDD-methodology. 
Table

Dynamics of the consumption of ADs in the pulmonary department of the multi-specialty hospital

\begin{tabular}{|l|c|c|c|c|c|c|}
\hline \multicolumn{1}{|c|}{ Group of drugs } & 2011 & 2012 & 2013 & 2014 & 2015 \\
\hline \multicolumn{4}{|c|}{ Consumption of ADs, DDD/100 bed-days } \\
\hline Fluoroquinolones & 13.49 & 8.89 & 8.46 & 2.77 & 4.16 \\
\hline Cephalosporins & 8.53 & 13.72 & 7.47 & 12.51 & 19.47 \\
\hline Aminoglycosides & 3.31 & 0.58 & 3.28 & 3.45 & 1.92 \\
\hline Penicillin & 1.82 & 0.84 & 0.33 & 0.51 & 0.33 \\
\hline Macrolides & 0.66 & 1.38 & 0.83 & 0.42 & 0.31 \\
\hline Lincosamides & 0.23 & 1.04 & 0.23 & 0.35 & 0 \\
\hline $\begin{array}{l}\text { Total consumption } \\
\text { of ADs, DDD/100 } \\
\text { bed-days }\end{array}$ & $\mathbf{2 8 . 0 4}$ & $\mathbf{2 6 . 4 6}$ & $\mathbf{2 0 . 6 1}$ & $\mathbf{2 0 . 0 1}$ & $\mathbf{2 6 . 1 9}$ \\
\hline
\end{tabular}

\section{Materials and Methods}

The study was conducted at the premises of the pulmonary department of the regional clinical hospital (Khujand, the Republic of Tajikistan). The retrospective escriptive analysis of prescribing pharmacotherapy for patients being treated in this department was performed. The nosological structure of cases of hospitalization in this department, requiring antibiotic therapy, included acquired pneumonia and exacerbation of chronic obstructive pulmonary disease. The use of ADs in total, by groups according to the ATC/DDD Index of the WHO [9]: penicillins, cephalosporins, aminoglycosides, fluoroquinolones, tetracyclines, other antibiotics, as well as separately by International Nonproprietary Names of drugs was assessed. As a unit of measurement the grams of the active substance was used with the subsequent calculation of the indicator of DDD/100 bed-days and the percentage of the total DDD. To evaluate the results of the study, calculate descriptive statistics and plot graphs the software resources of Microsoft Office Excel package 2007 was used.

\section{Results and Discussion}

The DDD-analysis of AD consumption in the pulmonary department of the multi-specialty hospital for five years showed that despite the fact that the total AD consumption of pulmonary department in dynamics (total $\mathrm{DDD} / 100$ bed-days) was practically the same and fluctuated within 20.01-28.04 DDD/100 bed-days, the struc-

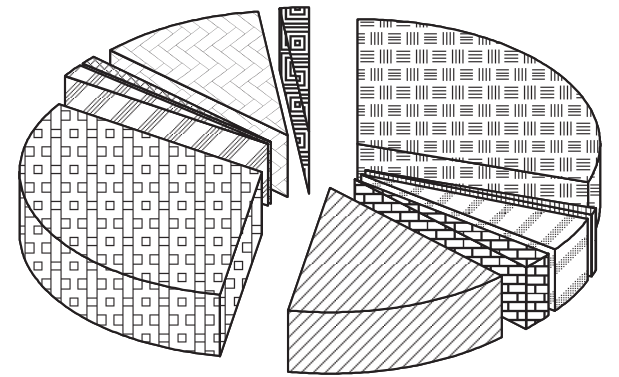

ture of AD consumption significantly changed. For example, if in 2011 the basis for the antimicrobial treatment of respiratory tract infections (RTI) was fluoroquinolones and cephalosporins, much less penicillins and aminoglycosides, by 2015 cephalosporins were in the vast majority of prescriptions. As shown in Table, in 2011 the most consumed group of ADs were drugs from the group of fluoroquinolones, which $\mathrm{DDD} / 100$ bed days was 13.5 DDD. However, in subsequent years the interest to this group of ADs gradually declined, and by 2015 the consumption of drugs of this group was 3 times less than in 2011. At the same time, since 2012 mainly antibiotics of the cephalosporin group were prescribed for the treatment of RTI, their consumption increased by more than 2 times in 2015 (8.5 DDD/100 bed days in 2011 and 19.5 DDD/100 bed-days in 2015, respectively).

It is important to note the decreased interest to ADs from the group of penicillins, macrolides and aminoglycosides in dynamics. This fact requires in-depth analysis since, according to the international recommendations, the starting antibiotic therapy of RTI and, primarily pneumonia, should be carried out with ADs from the group of penicillins and macrolides (when suspecting the atypical flora), or protected penicillins or cephalosporins of the 3rd generation as the drugs of choice for severe RTI, first of all, pneumonia [10].

Further in-depth analysis of the structure of AD consumption in the pulmonary department of the multi-specialty hospital is presented in Fig. 1-3.

It was found that there was a two-fold increase in the consumption of cephalosporin antibiotics during this period, first of all, cephalosporins of the 3rd generation, namely ceftriaxone, the most commonly used drug of the cephalosporin group. So, the proportion of ceftriaxone of the total DDD was $29.6 \%$ in 2011. Further by 2015 this indicator increased almost 2.5 times (Fig. 1). In other words, an increase in using cephalosporins for the study period was exclusively due to cephalosporin of the 3-rd generation - ceftriaxone, its share in the total consumption in 2015 was almost $74 \%$ of the DDD. Only once the use of cefazolin, cefepime, ceftazidime (less than $1 \%$ of the total DDD) was observed.

The frequency analysis of the use of antimicrobial drugs from the fluoroquinolone group for treating RTI showed that in all periods of observation drugs of this-

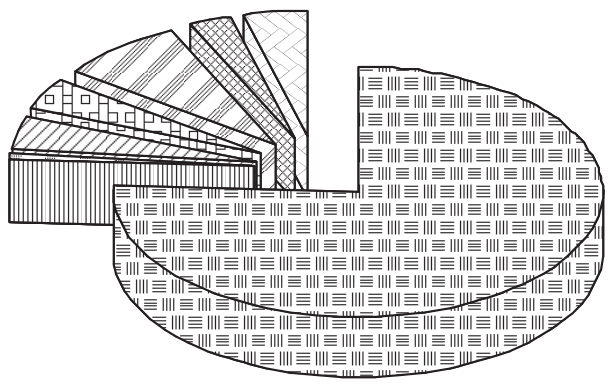

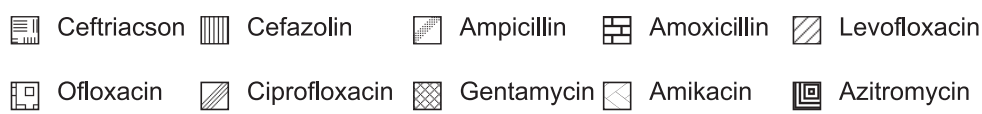

Fig. 1. The DDD-analysis of AD consumption in the pulmonary department in dynamics (\% of the total DDD) 


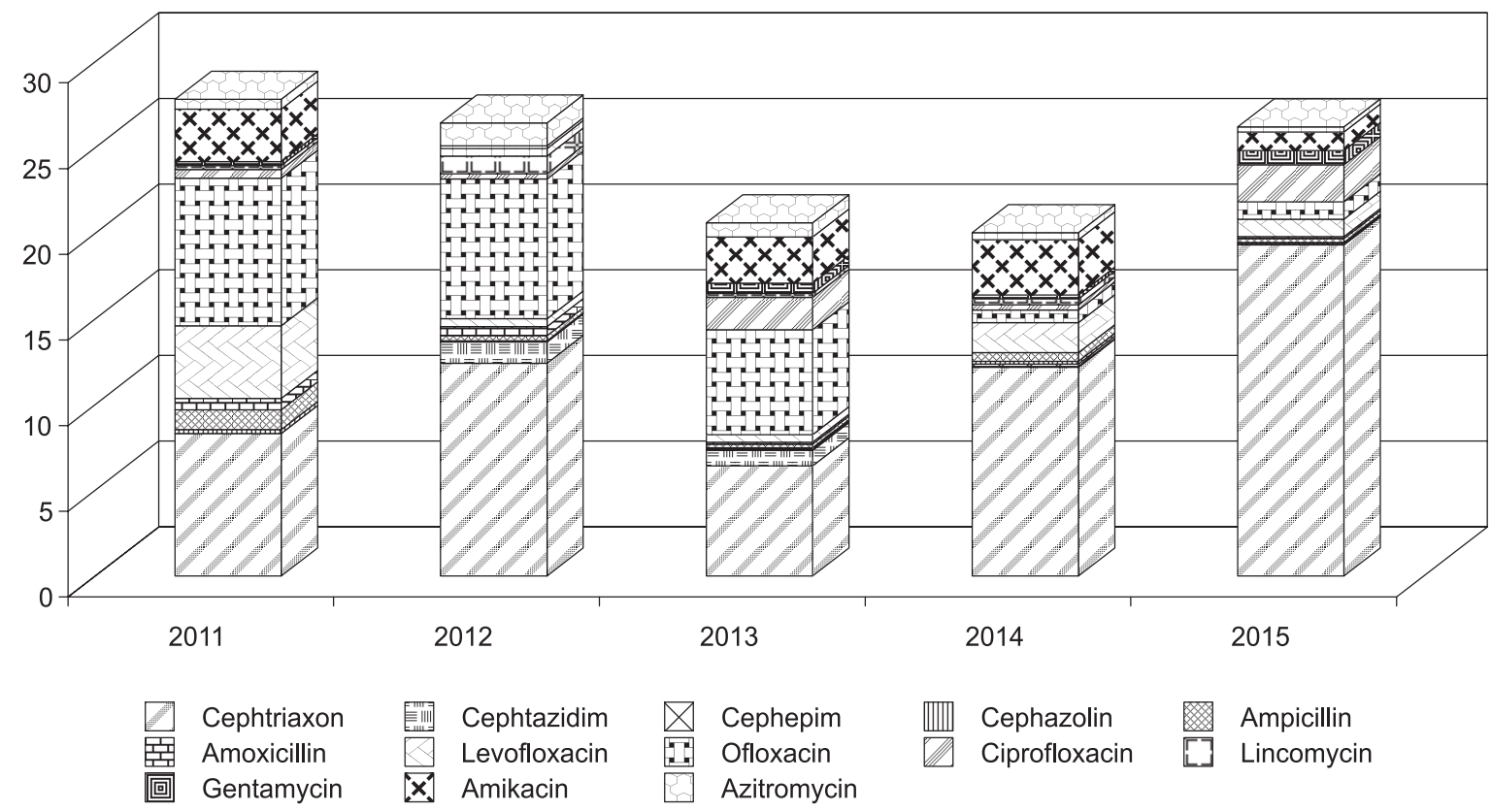

Fig. 2. Dynamics of $A D$ consumption in the pulmonary department of the multi-specialty hospital (DDD/100 bed-days)

group ranked second, averaging approximately $30 \%$ of the total DDD in 2011-2013 (ofloxacin) and approximately $15 \%$ of the total DDD in 2014-2015 (levofloxacin and ciprofloxacin). A similar pattern was observed when analyzing the level of $\mathrm{AD}$ consumption of this group by the number of DDD/100 bed-days (Fig. 2). Thus, there was a clear downward tendency in the use of ofloxacin and levofloxacin, and a slightly increased interest in ciprofloxacin. The data obtained confirm again a significant change in approaches to the starting antibiotic therapy of RTI using mainly cephalosporins of the 3-rd generation, namely ceftriaxone.

Importantly, there is a strong interest to aminoglycoside antibiotics when treating RTI. However, until
2015 there was a clear tendency of the decreased interest to this group of medicines. Fig. 3 shows that the percentage of the total DDD of amikacin was from $10.9 \%$ to $16.0 \%$ within $2011-2014$. It was only in 2015 that the percentage of the total DDD of the drug was $4.2 \%$. Moreover, DDD/100 bed-days of amikacin within the time specified was 2.7-3.2 DDD in 2011-2014 and 1.09 DDD in 2015 (Fig. 2).

Another member of aminoglycoside group - gentamicin sulfate was rarely used to treat RTI, its percentage of the total DDD was $0.9-3.2 \%$ in different years. A rather strong interest to ADs of this group, in particular to amikacin, can be explained only from the point of view of the test results on the microflora sensitivity to

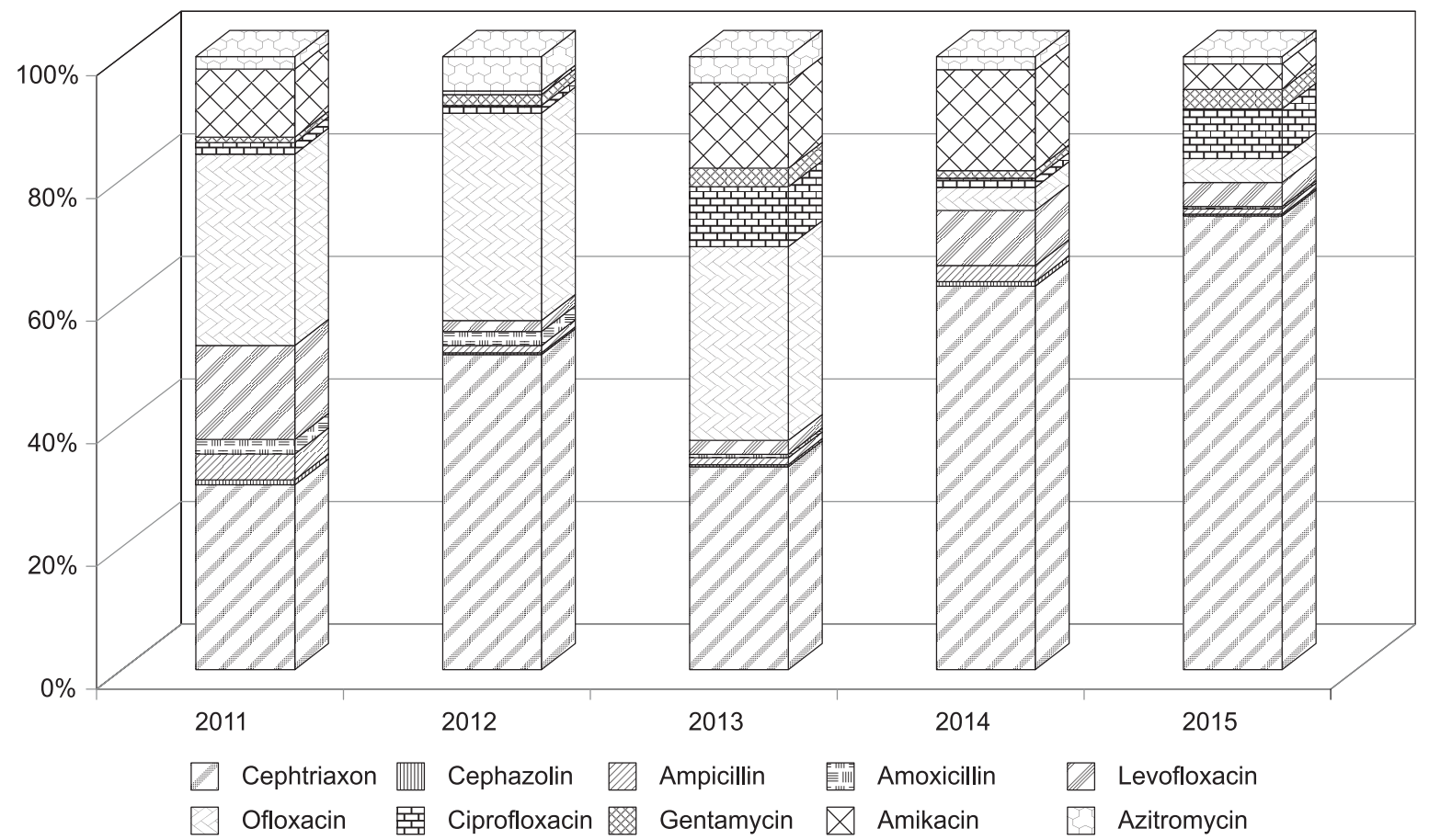

Fig. 3. Dynamics of $A D$ consumption in the pulmonary department of the multi-specialty hospital (\% of the total DDD) 
ADs since this group of drugs is not included in any of the lists of recommendations for empiric antimicrobial therapy of RTI. Aminoglycosides have a relatively narrow spectrum of activity aimed mainly on the gram-negative flora, anaerobes, staphylococci, etc. As a rule, they have very low activity against pneumococci, Haemophilus influenzae, and intracellular pathogens, i.e. for the most frequent etiological factors of RTI. The expedience of using these drugs occurs only in severe disease course or in the presence of co-morbidities and risk factors, which worsen the prognosis of the disease or associated with the gram-negative microflora and anaerobes.

It is worth noting that there was a significant reduction of interest to ADs of the penicillin group, which share decreased by 5 times in the structure of AD consumption in the pulmonary department, and in 2015 it was $0.84 \%$ of the total DDD for ampicillin and $0.42 \%$ for amoxicillin (Fig. 3). Moreover, there was unreasonably rare use of augmentin as the initial therapy of RTI.

Considering the available literature information and international guidelines for the treatment of RTI today it is penicillins, in particular amoxicillin, that are considered to be the most effective drugs for the initial empirical antimicrobial therapy of diseases of the respiratory system in which S.pneumonia is the most common and significant etiopathogen with high sensitivity to ADs from the group of penicillins and with the best "safety profile" [10]. As the available literature shows, this tendency is typical for most European countries. For example, in 6 states of Europe the share of inhibitor-protected penicillins in the total consumption of this
$\mathrm{AD}$ group exceeded $50 \%$ [5]. The data obtained require analysis of the current situation in the Republic of Tajikistan taking into account the regional peculiarities of the microflora sensitivity to ADs.

\section{CONCLUSIONS}

1. The DDD-analysis of the consumption of antimicrobial drugs on the example of the pulmonary department of the multi-specialty hospital has shown a significant change in the structure of the drug consumption in this group for the starting antibiotic therapy of respiratory tract infections over the past five years. The studies conducted have revealed a clear downward tendency in the consumption of drugs of penicillin and macrolides with the transition to monotherapy with cephalosporins of the 3-rd generation (ceftriaxone) and partially fluoroquinolones. For further analysis of the rationality of using ADs the data obtained should be compared with the results of the study of the antibiotic resistance in each specific department, city and the country as a whole.

2. Monitoring of the consumption of antimicrobials in in-patient departments using the ATC/DDD-methodology allows to make strategic decisions concerning the tactics of antibacterial therapy of diseases according to the department specialization, as well as to determine the direction of administrative measures for further improvement of the range of antibacterial drugs introducing modern effective products into practice and optimizing the consumption of antibiotics in each specific department.

Conflicts of Interest: authors have no conflict of interest to declare.

\section{REFERENCES}

1. Денисова, М. Н. Оценка потребления лекарственных средств. Использование методологии ATC/DDD [Электронный ресурс] / М. Н. Денисова. - Режим доступа : http://www.kstgroup.ru/apt_set/d_2006.ppt

2. Зайцева, А. А. Фармакоэпидемиологический анализ амбулаторной практики антибактериальной терапии внебольничных инфекций дыхательных путей / А. А. Зайцева // Рус. мед. журн. - 2012. - № 26. - С. 1317-1320.

3. Низтаева, Э. Н. Фармакотерапия и фармакоэкономика нетяжелых форм внебольничной пневмонии / Э. Н. Низтаева // Известия ВУЗов. - 2010. - № 5-6. - С. 309-313.

4. Паравина, Е. В. Комплексный анализ потребления антибиотиков в многопрофильном стационаре / Е. В. Паравина, А. В. Жестков, О. Л. Кулагин // Казанский мед. журн. - 2011. - Т. 92, № 4. - С. 581-584.

5. Лысенко, Г. В. Применение антибактериальных средств при внебольничной пневмонии. От обзора литературы и до собственных данных / Г. В. Лысенко // Вестник современной клин. медицины. - 2014. - Т. 7, вып. 4. - С. 53-56.

6. Беденков, А. В. Практическое применение ATC/DDD методологии [Электронный ресурс] / А. В. Беденков. - Режим доступа : www.antibiotic.ru/rspe/library/pr_bedenkov_ind.shtml

7. Рачина, С. А. Рекомендуемая BO3 ATC/DDD методология в исследованиях потребления лекарственных средств [Электронный pecypc] / С. А. Рачина. - Режим доступа : www.antibiotic.ru/rspe/library/pr_rachina_ind.shtml.

8. Gilbert, D. N. The Sanford guide to antimicrobial therapy / D. N. Gilbert, R. C. Moellering, G. M. Eliopoulo // Antimicrobial Therapy. 2010. $-220 \mathrm{p}$.

9. Guidelines for ATC classification and DDD assignment [Internet]. - Available at : http://www.whocc.no/atc_ddd_index.

10. Дьяченко, С. В. Фармакоэпидемиологический анализ использования антимикробных препаратов в круглосуточных стационарах Дальнего Востока России / С. В. Дьяченко // Вестник ВолГМУ. - 2009. - Вып. 1 (29). - С. 49-52.

\section{REFERENCES}

1. Denisova, M. N. Available at: http://www.kstgroup.ru/apt_set/d_2006.ppt

2. Zaiceva, A. A. (2012). Russkii medicinskii zhurnal, 26, 1317-1320.

3. Niztaeva, E. V. (2010). Izvestiia VUZov, 5-6, 309-313.

4. Paravina, E. V., Zhestokov, A. V., Kulagin, O. L. (2011). Kazanskii medicinskii zhurnal, 92 (4), 581-584.

5. Lusenko, G. V. (2014). Vestnik sovremennoi klinicheskoi meditsyny, 7 (4), 53-56.

6. Bedenkov, A. V. Available at: www.antibiotic. ru/rspe/library/pr bedenkov ind.shtml 
7. Rachina, S. A. Available at: www.antibiotic.ru/rspe/library/pr_rachina_ind.shtml.

8. Gilbert, D. N., Moellering, R. C., Eliopoulo, G. M. (2010). The Sanford guide to antimicrobial therapy. Antimicrobial Therapy, 220.

9. Guidelines for ATC classification and DDD assignment. Available at: http://www.whocc.no/atc_ddd_index.

10. D'iachenko, S. V. (2009). Vestnik VolGMU, 1 (29), 49-52.

\section{Information about authors:}

Savchenkova L. V., Doctor of Medicine (Dr. habil.), professor, head of the Department of Pharmacy, Tajik National University. E-mail: slv.05@mail.ru Saidova M. N., Candidate of Pharmacy (Ph.D.), associate professor of the Department of Pharmacy, Tajik National University.

Sanginova N. S., teaching assistant of the Department of Pharmacy, Tajik National University

Dzhabarov I. P., teacher, Y. B. Iskhaki Khujand State Medical College

Відомості про авторів:

Савченкова Л. В., д-р мед. наук, професор, завідувач кафедри фармації, Таджицький національний університет. E-mail: slv.05@mail.ru

Саїдова М. Н., канд. фарм. наук, доцент кафедри фармації, Таджицький національний університет

Сангінова Н. С., асистент кафедри фармації, Таджицький національний університет

Джабаров І. П., викладач, Медичний коледж імені Ісхокі Ю. Б., м. Худжанд

Сведения об авторах:

Савченкова Л. В., д-р мед. наук, профессор, заведующая кафедрой фармации, Таджикский национальный університет. E-mail: slv.05@mail.ru

Саидова М. Н., канд. фарм. наук, доцент кафедры фармации, Таджикский национальный университет

Сангинова Н. С., ассистент кафедры фармации, Таджикский национальный университет

Джабаров И. П., преподаватель, Медицинский колледж имени Исхоки Ю. Б., г. Худжанд 